\title{
Nutritional Issues Concerning Street Foods
}

\section{Abstract}

The aim of this review of the literature is to present considerations focused on nutritional issues related to street foods. More specifically, in this paper were analyzed the characteristics of street foods with emphasis placed upon food security and nutrition, food safety, risk of foodborne diseases, overweightness and obesity, as well as other chronic non-communicable diseases. Street foods are a source of culturally accepted, inexpensive, convenient and often appealing foods for both urban and rural people worldwide. However, street foods are often seen as possessing nutritional components associated with an unhealthy diet and potentially holding a higher risk of contamination by physical, chemical and biological agents, i.e., become a serious concern in terms of food safety. Street foods can cause the emergence of foodborne diseases, due to the ease of contamination by pathogenic and non-pathogenic microorganisms, and the development of chronic non-communicable diseases, since the street foods usually have high quantities of carbohydrates and fats. In summary, the consumption of street foods contributes towards a given population meeting their nutritional needs. However, due to the lack of facilities in street mobile vending of foods, cheaper raw materials, as well as insufficient knowledge of good manufacturing practices linked to street vendors, street foods may cause foodborne diseases and chronic non-communicable diseases. The establishment of specific legislation can contribute to nutrition security of the street foods and public health.

Keywords: Street foods; Food security and nutrition; Food safety; Foodborne diseases; Chronic non-communicable diseases

Received: November 24, 2015; Accepted: April 05, 2016; Published: April 12, 2016

\section{Isabella Lopes Nonato ${ }^{1,2}$, Luciana Oliveira de Almeida Minussi ${ }^{1,2}$, Grazieli Benedetti Pascoal' and Daurea Abadia De-Souza ${ }^{1-3}$}

1 Faculty of Medicine, Federal University of Uberlândia, Uberlândia, MG, Brazil.

2 Postgraduate Program in Health Sciences, Faculty of Medicine, Federal University of Uberlândia, Uberlândia, MG, Brazil.

3 Department of Internal Medicine, Faculty of Medicine, Federal University of Uberlândia, Uberlândia, MG, Brazil.

\section{Corresponding author:}

Daurea Abadia De-Souza

झ daureas@ufu.br

MD, PhD, Faculty of Medicine, Federal University of Uberlândia. Avenida Pará, 1720- Bloco 2U, Sala 23, Campus Umuarama, Postal Code: 38.405-320, Uberlândia, Minas Gerais, Brazil.

Tel: +55 34 3225-8602

Citation: Nonato IL, Minussi LOA, Pascoal $\mathrm{GB}$, et al. Nutritional Issues Concerning Street Foods. J Clin Nutr Diet. 2016, 2:1.

Food safety is a broad term that incorporates several conditions, which include the handling, preparation and storage of foods in terms of preventing foodborne diseases, i.e., illness caused by bacteria or other microorganisms, including toxins in foods [9]. Since the points of sale of the mobile vendors that sell foods in the streets usually do not have the same facilities available in formal shops, street foods are included among those factors responsible for foodborne diseases [10].

The aim of this review of the literature is to present considerations regarding nutritional issues related to street foods. More specifically, in this paper were analyzed the characteristics of street foods with emphasis placed upon food security and nutrition, food safety, risk of foodborne diseases, overweightness and obesity, as well as other chronic non-communicable diseases. 


\section{Methods}

A search using the terms street foods, street foods and nutrition, street foods and food safety, street foods and food security, street foods and foodborne diseases, street foods and chronic non-communicable diseases was conducted from January 2011 until January 2016. The database included MEDLINE/PUBMED. Selected for this search were the filters tuned to only full text, English language, and research carried out with human subjects. The authors performed a manual search of the reference lists, documents published by reputable worldwide organizations and model research of the included articles was conducted to find additional studies missed by database searches (Figure 1).

\section{Food security, nutrition and health}

The concept of the food security involves primarily the physical determinants of the food flow, i.e., the availability, accessibility, and utilization of appropriate foods by individuals of a population. These physical elements are affected by stability, a temporal determinant of food security [11]. In addition, due to the increased number of foodborne diseases caused by microorganisms and chronic non-communicable diseases, the concept of healthy foods has been discussed in function of the risks caused by food. In accordance with these considerations, the definition of nutrition security should include all determinants of food security, besides health services and environmental conditions. All of these determinants are essential elements of appropriate health status and nutritional health status [11]. Currently, food security and nutrition has generated discussions principally between governmental and educational institutions, centered upon programs that ensure foods and its manufactured products attainable to the population are safe and healthy [1].

Discussions focused upon food security and nutrition go back to the first half of the 20th century, gaining prominence on the world stage with the creation, in 1963, of the Codex Alimentarius by the Food and Agriculture Organization (FAO) and World Health
Organization (WHO). The Codex Alimentarius is considered a central tool grounded on scientific principles and guidelines governing various questions concerning food. The Codex Alimentarius has as its main objectives to protect consumer health by ensuring food security, promotion of a healthy food and reducing the risk of chronic non-communicable diseases, and to ensure adequate practices in food preparation through the development of food standards, guidelines, codes of conduct and other recommendations [12].

The standards and guidelines set by Codex Alimentarius are relevant in the contemporary world scene, for example, in food hygiene and contaminants [7, 13]. However, there is a lack of norms and specific patterns for regional foods and preparations, including street foods. Although it is understandable that this central question arises due to the logistical challenges of assessing moving targets, such as, mobile food vendors [14], the failure in establishing standards and guidelines set by Codex Alimentarius contributes to the manifestations of foodborne diseases, chronic non-communicable diseases, and diseases associated with physical, chemical and other agents. Knowledge and understanding concerning the nutritional issues related to street foods are fundamental to their regulation [15].

\section{Nutrition security and mobile food trade}

The informal economy can be conceptualized as a complex area of economics, which has grown and has great potential to continue growing throughout the world [2]. The informal economy includes an increasing number of workers and urban and rural companies that operate in several business areas, without any official registration formalized with competent agencies [16, 17]. These professional activities include areas of self-employment dedicated to subsistence activities; wage earning employees, who are not legalized; and employees providing outsourced service and casual labor $[16,17]$. Among the numerous examples of jobs that integrate the informal economy, street vending is included, which has been classified into three main categories:

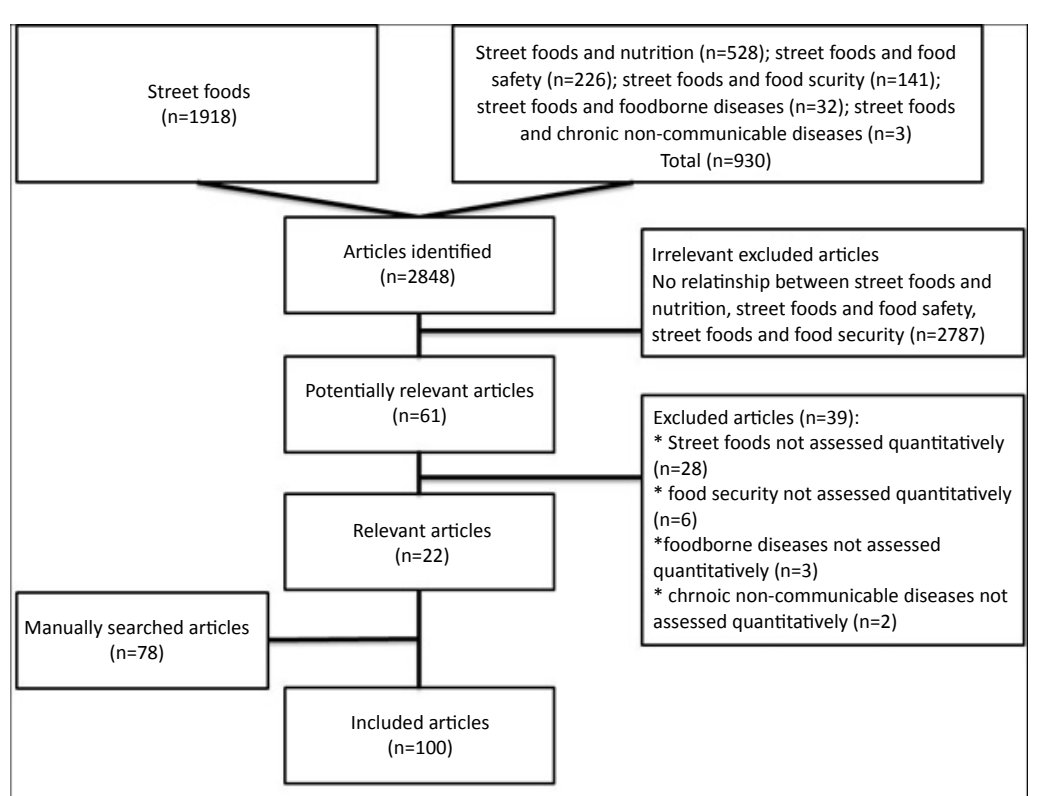

Figure 1 Flow chart showing the selection of studies. 
mobile, semi mobile and fixed $[18,19]$. Among the mobile traders are the food vendors, which play an important role for a variety of groups [20].

Changes in lifestyle within society and its classes have motivated the street foods trade, especially in large urban centers, as consumers often work far from their homes, making access difficult at mealtimes. In addition, the inclusion of women in the labor market, replacing domestic activities by working outside the home, has contributed to the family members to consume street foods. Street food vending generates significant employment in urban areas, which is important in alleviating poverty, the major causative factor in food insecurity [21]. The mobile street foods practice is one of the multiple survival strategies adopted by poor urban households to maintain and expand the base of subsistence incomes especially in the surge of economic crisis [22]. It also provides a viable alternative to formal employment [4]

Although the sale of street foods is often associated with poor countries and/or those in development [23], with limited employment opportunities, low wages and fast urbanization, the practice of street foods vendors can be widely found in those countries considered as developed. All over the world, street foods provide a wide range of commodities and energy/ nutrients, helping people to meet their nutritional needs. Indeed, easy accessibility, variety in taste and choice, and low cost make street foods an affordable option [5, 24-26].

However, in several studies the occurrence of serious public health problems related to street mobile vending of food has been reported, especially the difficulty found in the control of sanitary quality [2]. This issue is related to the mobility of mobile vendors, temporary nature of the activity $[27,28]$ and the increased exposure of the food [29]. It is recognized that street foods vendors generally have insufficient knowledge of good manufacturing practices and belong to poor socioeconomic groups $[2,30]$. Inadequate knowledge of street food vendors about basic food safety measures, poses risks of spreading foodborne diseases within the community $[30,31]$. An additional issue, but not the least, is the lack of facilities in street mobile vending of foods, such as clean water for hand hygiene and utensils [32-34] and electric power for storage and maintenance of food temperatures [35-37]. Regulatory agencies have established temperatures for food preservation, i.e., fruit and vegetables at $50^{\circ} \mathrm{F}\left(10^{\circ} \mathrm{C}\right)$; cold and dairy products at $46.4^{\circ} \mathrm{F}\left(8^{\circ} \mathrm{C}\right)$; pork and poultry meat at $39.2^{\circ} \mathrm{F}\left(4^{\circ} \mathrm{C}\right)$; fish at $35.6^{\circ} \mathrm{F}\left(2^{\circ} \mathrm{C}\right)[38]$.

Although the mobile trend of street foods presents numerous problems, some benefits related to nutrition security have been reported, such as the strengthening of regional and traditional food habits; a quick, cheap and convenient way to consume food by people of low socioeconomic status; an attractive way for tourists to find regional foods, due to the varieties of regional foods on offer; an important source of income for a large number of people; and a chance for self-development and the opportunity to grow into a private business without the need for large capital investment $[39,40]$.

In summary, although the creation of specific local regulations for mobile trade of food is not sufficient to solve all the problems related to street foods, it is very important to ensure nutrition security to consumers. This consideration emphasizes the need for government action in order to establish specific legislation to ensure that food sold in public places has good sanitary conditions and nutritional quality.

\section{Nutrition security and street foods}

Three distinct categories of street foods can be identified, i.e., food prepared in small factories and sold by mobile vendors; food prepared at mobile vendors home and offered for sold to the public; and food prepared and sold on the street [18]. Often, the foods sold by mobile vendors are offered at low cost and at easily accessible locations, such as streets, bus terminals, parks, schools, hospitals, and railway stations [19, 41-43]. In general, the main food sold on the streets of various countries are hot dogs, hamburgers, fruits, vegetables (United States - USA, Brazil); donuts, nuts (USA); pastries, churros, popcorn, acarajé (Brazil); snakes (USA, Brazil, European countries); taco, burrito (USA, Brazil, Mexico); finger foods (USA, Brazil, European countries, Argentina); yakissoba (Brazil, China); tempura (China); benthos (Brazil, Japan), among other [2].

Despite the emergence of modern fast food, traditional street foods persist worldwide, especially in Europe and Mediterranean countries [17], contributing to the preservation of local traditions [44] and may be particularly important food sources in minority and low-income communities [14, 45-48]. In a study developed by Steyn et al. [49], the street foods and fast foods consumption patterns in South Africa were surveyed from a nationally representative sample $(n=3287)$. The frequency (two or more times a week) of the street foods and fast foods consumption by South Africans was high, i.e., up to $20.6 \%$ and $14.7 \%$, respectively. Fruit was the most commonly purchased street food by all ethnic groups, although this practice was highest in black participants (35.8\%). The investigators demonstrated that despite this being considered an example of a good food habit more frequently street foods consumers had a significantly lower dietary diversity score in comparison to fast foods consumers [49].

In countries with very low income per capita, as for example, Haiti, members of the local population have the practice of consuming and marketing unconventional street foods, such as mud biscuits. Due to the inability to buy food, some Haitians add butter, salt and, eventually, vegetables to the yellow mud and place the cookies to dry in the sun, on the ground, in large areas uncovered. These mud cookies are used for their own consumption, including children, but can also be traded, representing a source of income for many families where there exists serious food insecurity [50-53]. This practice illustrates that even in countries with extreme poverty, the sale of street foods can be a professional activity, which gives some kind of income in countries with very few formal jobs and incipient public health policies for the population.

According to a survey conducted by FAO [39], in the year of 2001 approximately 2.5 million people consumed food on public roads (about $0.03 \%$ of world population). Safeguarding the proper proportions between the results of a worldwide survey [39] and a study in a specific geographical location, to low values as consumption of street foods are not always reported. An 
example is a study realized by Riet et al. [54], who investigated men with a low socioeconomic standard of living in South Africa $(n=241)$. Analyzing men who lived in a low-income area (Dandora neighbourhood, $n=129$ ) or in places of extreme poverty (Korogocho neighbourhood, $n=112$ ), researchers demonstrated that $72 \%$ and $51 \%$ of study populations, respectively, performed corresponding to the lunch meal outside the home (purchase of food from street vendors fixed, mobile and other providers). In this study, the percentage of daily energy from street foods was also investigated. The researchers found that $22.7 \%$ (Korogocho) and $69.9 \%$ (Dandora) of daily energy consumed by these men came from street foods. Another example is a study developed by Wang et al. [55]. In this study developed analyzing children in China, it was demonstrated that about $10 \%$ of the students consumed street foods frequently (more than three times a week), with higher percentage among migrant students $(12.2 \%$ vs. $8.5 \%)$.

Analyzing concomitantly the results published by FAO, in the year 2001 [39], and Riet et al., in the year 2002 [54], it is possible to conclude that there are high distortions in the reports on the consumption of street foods, probably due to the level of socioeconomic development of these geographical locations of South Africa. In addition, is also possible to interpret that the FAO data are underestimated, since the consumption of street foods is not a practice of compulsory notification. One possible interpretation is that the FAO results express average values for population groups, which prevents the viewing of extreme values on the very low and very high consumption of street foods. On the other hand, the inhabitants of South Africa may have a reported frequency of consumption of street foods higher than the actual, by the possible embarrassment of being classified in a situation of food insecurity and/or hunger.

Street foods can induce serious health problems, particularly for the inappropriate chemical composition, exemplified by high levels of carbohydrates and fats, including saturated fats [56]. One of the few studies evaluating the potential role of street foods as micronutrients source among lower-income groups was developed in Nairobi, Kenya [57]. These investigators demonstrated that although absolute vitamin $A$, iron and zinc intake from street foods are lower among the low-income groups as compared to middle-low income groups, these variations were not significant, except for zinc. Street foods are better dietary sources of iron (26\% of total intake) and zinc (21\%) than of vitamin A (12\%).

These questions may be associated with the option to the use of cheaper raw materials, but of dubious quality, both in terms of hygiene and health, as well as in relation to the nutritional composition [23, 40,58]. In this way, in addition to the high risk of chemical, physical and microbiological contamination, the composition of street foods could be associated with the emergence of chronic non-communicable diseases, particularly when street foods are consumed frequently and in large quantities, being an important matter of nutrition security $[59,60]$.

In summary, the evaluation of street foods exclusively as a public health problem, i.e., the supply of safe food, which contributes to the nutritional health status, is limited in scope. Several social, cultural and economic issues influence this practice. A poor production and marketing of the street foods exemplified by the use of cheaper inputs and of dubious quality, as well as the lack of nutritional knowledge security on the part of the handlers, compromises the nutritional quality and sanitaryhygiene of food. In this way, it is necessary that a commitment from the population in the search of effective educational actions arising out of local public policies is created, aimed at imparting the knowledge concerning food safety and food security. Thus, a knowledge and understanding of the complexity of this reality is fundamental in efforts for its regulation within the context of working with intersectoral demands. This conduct should be the course of action taken to care for the health of the population in general, avoiding the risks of foodborne diseases and chronic non-communicable diseases.

\section{Street foods and foodborne diseases}

Foodborne diseases are caused through the ingestion of water or food contaminated by pathogenic microorganisms, toxins, chemical or physical agents $[61,62]$. In contrast to the developments of techniques surrounding food preservation and hygiene [63], foodborne diseases still persist as one of the major public health problems worldwide [64].

An outbreak of foodborne diseases is defined as an incident in which two or more people experience a similar illness after eating the same contaminated food $[61,65]$. The signs and symptoms that more often appear after the ingestion of contaminated water and/or food are nausea, vomiting, cramp pain, diarrhea and fever. The intensity and severity of these manifestations are directly related to the quantity and type of microorganism or toxin accidentally ingested [54]. In healthy adults, the evolution of foodborne diseases usually is self-limiting, not causing complications that are more serious. However, for individuals at highest risk, such as children, pregnant women, elderly, malnourished and/or immunocompromised patients, the clinical manifestations may be more severe and prolonged, progressing to bloody diarrhea, acute renal failure, bacteremia, sepsis and even death [64].

Although there are many agents responsible for outbreaks of foodborne diseases, the most common are Bacillus cereus, Campylobacter spp., Clostridium spp., Escherichia coli, Listeria monocytogenes [66], Salmonella spp., Shigella spp., and Staphylococcus spp. $[9,10,67-70]$. Despite this wide variety of etiologic agents, the Salmonella spp. stands out as a common microorganism, being responsible for $76 \%$ of foodborne disease outbreaks in Austria [71]; 70\% of foodborne disease outbreaks in the United States of America, Canada, European Union, Australia and New Zealand [72], and 52\% of foodborne disease outbreaks in England and Wales [73]. In addition, in 2005, in France, the Salmonella spp. present in contaminated food was the main cause of hospitalization and death from bacterial gastroenteritis [74].

The street foods trade in public places can constitute a potential vehicle for the emergence of the foodborne diseases, due to the facility of food contamination with pathogenic or non-pathogenic 
microorganisms $[37,39,75]$. In fact, the nutrition security of street foods has been one of the major concerns for public health, since the potential for no safety or no sanitary handling food by mobile food vendors is common [9, 75]. Street vended foods are usually produced in small mobile units (e.g., vans, trailers or carts) from which food are sold. These points of sale usually have an inadequate layout and equipment, poor environmental sanitation, improper food handling and storage practices, as well as low quality of raw materials $[9,59,75,76]$.

In accordance with these considerations in a study realized in one developed country (Portugal), it was demonstrated that readyto-eat street foods from vending trailers are potential vehicles of clinically relevant Listeria monocytogenes serotypes and Escherichia coli [77]. This study demonstrated that food-handlers' hygiene status contributed to the poor microbiological quality and safety of these products. In addition, in another study realized in India was showed that despite the fact that street food vendors have a minimum level of education and food safety knowledge, many such vendors were not following minimum food safety and personal hygiene practices [78]. In contrast, in a study developed in Nigeria using an observational checklist was showed that food vendors had good food handling practices and which street food vending sites were sanitary [79].

Ready-to-eat foods, particularly those which are composed of meat/poultry and salads, prepared and/or sold by vendors in streets have been recognized as potential vehicles of foodborne disease (e.g. Salmonella, Listeria monocytogenes, enteropathogenic, Escherichia coli) [9, 66, 70, 80]. Moreover, a growing food safety hazard has been noted, related to the role of food in human exposure to antimicrobial resistant bacteria, either zoonotic, commensal or from environmental origin [81, 82].

Although food products of animal origin are considered the main source of antibiotic resistance dissemination, fresh food of plant origin, such as salads, frequently used in ready-to-eat street foods/meals, is becoming a current concern $[82,83]$.

Several studies on microbiological hazards in street vended foods have been carried out in a number of developing countries [9, 84]. However, data are more limited to toxicological hazards, and few systematic appraisals have been performed [23]. Indeed, toxicological hazards may be somewhat overlooked in developing countries, since they rarely cause acute clinical illness. Unchecked toxicants and various situations of exposure to pollutants may be highly relevant to the health of future generations' in developing countries [85].

Preventive measures such as, for example, sanitary health education of the population, are identified as strategies for reducing cases of foodborne diseases, complementing the public actions of inspection and regulation, and contributing to the nutrition security of the population $[3,14,78,86]$. The care in the handling of food is an important step in reducing the incidence of foodborne diseases, especially for perishable foods. In addition, identifying and assessing possible toxicological risks would allow a more effective protection of the street foods system by addressing other relevant preventive actions [23]. These questions point to the need for investigating the microbiological quality and possible toxicological risks of street foods, whereas that usually have in their composition ingredients of animal origin highly perishable, i.e., require special conditions for storage and handling.

\section{Street foods and chronic non-communicable diseases}

The concept of nutrition transition is to change the dietary patterns of populations. Nutrition transition has contributed to accelerating the epidemiological transition, in other words, a gradual increase in chronic non-communicable diseases [86], such as overweightness and obesity, type II diabetes, arterial hypertension, dyslipidemia, cardiovascular disease and cancer [87-89].

In the recent past, the main challenges in public health were protein-energy malnutrition, specific micronutrient deficiencies, and infectious diseases [1]. More recently, the main challenges in the public health area have been associated with the prevalence of diseases caused by eating foods high in fat (particularly, saturated fat) and sugar added, contributing to the higher energy density of foods [87]. These characteristics are commonly present in the nutritional composition of street foods.

Despite the fact that street foods have been sold for numerous decades and provide a source of income to many families, there is a dearth of data regarding the contribution of street foods to the nutritional value of the diet $[56,90,91]$. In the majority of studies was demonstrated that street foods contributed significantly to the diet of children and adults in developing countries, both in terms of the variety of food groups consumed and in terms of energy, protein and micronutrient intakes [4, 18, 54, 56, 92].

The nutritional value of street foods depends on the ingredients used and how they are prepared, stored and sold, as occurs with other foods. It is essential to have a good understanding of the type and nutritional value of street foods since their consumption in many countries has become entrenched in habitual eating patterns and may influence the development of chronic noncommunicable diseases and other nutrition-related conditions in the population $[56,90,91]$.

Street food ingredients are country/region specific and rarely they are reported and/or analyzed [4, 93]. In a study developed in various locations in Abeokuta, Nigeria, chemical composition of seven common foods, i.e., cooked rice, cooked beans, cooked yams, cooked fufu, fried fish, stew, and vegetable soup, sold by the selected vendors was investigated. The results of the protein and fat content varied from $0.03 \%$ and $0.03 \%$ of the total caloric value in cooked fufu to $14.47 \%$ and $34.43 \%$ of the total caloric value in fried fish, respectively. The energy content ranged from $89 \mathrm{kcal}$ in cooked fufu to $375 \mathrm{kcal}$ in fried fish [94]. The results of this study allow us to interpret that street foods provide variable quantities of nutrients and energy to the consumers, i.e. to ensure the nutritional quality of the diet of people who consume street foods it is essential that the nutritional composition of each street food be analyzed and reported.

Higher street foods consumers may have unfavorable metabolic and cardiovascular effects, such as overweightness and obesity, 
higher serum cholesterol levels and cardiovascular risk [95, 96]. In a study performed in Palermo, Italy, an investigation of consumers of street foods $(n=687)$ and conventional restaurant food consumers ( $n=315)$ was made. Study subjects answered a questionnaire concerning their health conditions, nutritional preferences, frequency of consumption of street foods and a score relative to street foods consumption ranging from 0 to 20 was calculated. The investigators demonstrated that body mass index $\left(\mathrm{kg} / \mathrm{m}^{2}\right)$ was significantly and independently correlated with the score of street food consumption ( $r=0.103$; $p<0.002$ ), i.e., usual consumption and the highest street food consumption score were directly associated with the development of overweightness and obesity. The prevalence of other chronic non-communicable diseases, including hypertension and type 2 diabetes, and the use of medications did not differ between street foods and conventional restaurant food consumers [95].

In an additional study developed by the same group in Italy was investigated if street foods consumption has unfavorable metabolic and cardiovascular effects ( $n=1002$ health people). The researchers demonstrated that high street foods consumers (street foods score range seven to twenty) had a higher body mass index $(p=0.026)$, larger waist circumference $(p=0.041)$, higher levels of cholesterol $(p=0.013)$ and uric acid serum concentrations $(p=0.002)$ compared with low street foods consumers (street foods score range zero to one). In addition, it was demonstrated that the high street foods consumers had a significantly lower brachial artery flow-mediated dilatation, a measure of endothelial function, than the low street foods consumers. In summary, high street foods consumption may be associated with endothelial dysfunction in healthy people and high cardiovascular risk particularly in predisposed persons [96]. Other investigators previously demonstrated similar results [97-99].
According to this review of scientific studies focused on street foods, it is possible to infer that the food sold by mobile street vendors generally presents a poor nutritional quality. This assumption is related to the prospect of quick profit and use of cheaper raw materials $[9,59,75,100]$. Generally, this consists of energy dense meals, rich in saturated fats and sugar; with variables quantity and quality of protein; and poor in vitamins. Although a greater number of studies should be developed, it is possible to infer that street foods could be identified as a problem of nutrition security, contributing to the development of foodborne diseases and chronic non-communicable diseases, especially among high street food consumers who consume foods of this type more often.

\section{Conclusion}

Street foods are convenient, cheap, easily accessible and a source of income to many poor people who would otherwise not find employment. In addition, street foods contribute to the diet of many people worldwide. However, the difficulty of sanitary quality control and the low nutritional quality of street foods can be a threat to consumer's health in terms of nutritional security. Street foods could be associated with the emergence of foodborne diseases, due to the ease of contamination by several agents, including pathogenic microorganisms. In addition, street foods could also be associated with the development of chronic non-communicable diseases, since street foods usually have high quantities of carbohydrates and fats. These issues indicate that pertinent health authorities should regulate the marketing of street foods and initiate appropriate training programs for schoolbased street food vendors, for example in foodborne diseases, food safety, and food security. Simultaneously, incorporation of food safety and food security messages into textbooks and school curriculum would provide opportunities for increasing awareness of people regarding food security and nutrition. 


\section{References}

1 World Health Organization (2002) WHO global strategy for food safety: safer food for better health. Geneva: WHO Library Cataloguing-in-Publication Data.

2 World Health Organization (1996) Essential safety requirements for street-vended foods. Food Safety Unit Division of Food and Nutrition.

3 Food and Agricultural Organization of the United Nations (2013) Food for the cities: Street foods.

4 Namugumya BS, Muyanja C (2011) Contribution of street foods to the dietary needs of street food vendors in Kampala, Jinja and Masaka districts, Uganda. Public Health Nutrition 15: 1503-1511.

5 Ohiokpehai O (2003) Nutritional aspects of street foods in Botswana. Asian network for scientific information Pakistan J Nutr 2: 76-81.

6 Muinde OK, Kuria E (2005) Hygienic and sanitary practices of vendors of street foods in Nairobi, Kenya. Afr J Food Agr Nut Dev 5-7.

7 Choudhury M, Mahanta L, Goswami J, Mazumder M, Pegoo B, et al. (2011) Socio-economic profile and food safety knowledge and practice of street food vendors in the city of Guwahati, Assam, India. Food Control 22: 196-203.

8 Nonato IL, Fonseca VRS; Paz JG, Nomelini QSS, Pascoal GB, et al. (2012) Sanitary-hygienic quality of sale points and microbiological analysis of street food sold in the Umuarama Campus of the Federal University of Uberlandia. Biosci. J 28: 1061-1071.

9 World Health Organization - WHO/Food and Agriculture Organization of the United Nation - FAO. (2010) INFOSAN e Information note In Safety of street vended food $\mathrm{n} 3$.

10 Samapundo S, Climat R, Xhaferi R, Devlieghere F (2015) Food safety knowledge, attitudes and practices of street food vendors and consumers in Port-au-Prince, Haiti. Food Control 50: 457-466.

11 Gross R, Schoeneberger H, Pfeifer H, Preuss HJ (2000) The four dimensions of food and nutrition security: Definitions and concepts. SCN News 1-17.

12 Crane NT, Nalubola R, Schneeman BO (2010) The role and relevance of codex nutrition standards. J Am Diet Assoc 110: 672-682.

13 Informe 32a periodo de sessions Codex Alimentarius (2009) Programa conjunto FAO/OMS sobre normas alimentarias.

14 Lucan SC, Varona M, Maroko AR, Bumol J, Torrens L, et al. (2013) Assessing mobile food vendors (a.k.a. street food vendors) methods, challenges, and lessons learned for future food-environment research. Public Health 127: 766-776.

15 Silva SA, Cardoso RCV, Góes JAW, Santos JN, Ramos FP, et al. (2014) Street food on the coast of Salvador, Bahia, Brazil: A study from the socioeconomic and food safety perspectives. Food Control 40: 78-84.

16 Matalas AL, Yannakoulia M (2000) Greek street food vending: an old habit turned new. In: Street Foods. 86. In: Simopoulos AP, Bhat RV (eds.) World review of nutrition and dietetics Basel, Karger.

17 Organización International del Trabajo-OIT (2002) El trabajo decente y la economía informal. Conferencia Internacional del Trabajo, 90a Reunión.

18 Chakravarty I, Canet C (1996) Street foods in Calcutta. Food Nutr Agric 18: 30-37.

19 Tinker I (1997) Street foods: urban food and employment in developing countries. New York: Oxford U Press.
20 Días EM, Ramón CG, Lizana JL (2008) Trabajo informal: motivos, bienestar subjetivo, salud y felicidad en vendedores ambulantes. Psicologia em Estudo 13: 693-701.

21 Codjia G (2000) FAO Technical Support for Improvement within the Street Food Sector. Gauteng Province, Pretoria.

22 Acho-Chi C (2002) The mobile street food service practices in the urban economy of Kumba, Cameroon. Singapore J Trop Geogr 23 : 131-148.

23 Proietti I, Frazzoli C, Mantovani A (2014) Identification and management of toxicological hazards of street foods in developing countries. Food Chem Toxicol 63: 143-152.

24 Food and Agricultural Organization of the United Nations - FAO (1997). Street food. Food, Nutrition and Agriculture - 63. Report of an FAO Technical Meeting on Street Foods, Calcutta, India 6-9.

25 FAO (2007) Promises and Challenges of the Informal Food Sector in Developing Countries. FAO Rome 17.

26 Tinker I (2003) Street foods: traditional micro-enterprise in a modernizing world. Int J Polit Cult Soc 16: 331-349.

27 Hanashiro A, Morita M, Matt GR, Matté MH, Torres EAFS, et al. (2005) Microbiological quality of selected street foods from a restricted area of São Paulo city, Brazil. Food Control 16: 439-444.

28 Ghosh M, Wahi S, Kumar M, Ganguli A (2007) Prevalence of enterotoxigenic Staphylococcus aureus and Shigella spp. in some raw street vended Indian foods. Int J Environ Health Res 17: 151-156.

29 Altekruse SF, Street DA, Fein SB, Levy AS (1999) Consumer knowledge of food-borne microbial hazards and food-handling practices. J Food Prot 62: 1132-1135.

30 Al Mamun M, Rahman S Md M, Turin TC (2013) Knowledge and Awareness of Children's Food Safety Among School-Based Street Food Vendors in Dhaka, Bangladesh. Foodborne Pathog Dis 10: 323330.

31 Rane S (2011) Street Vended Food in Developing World: Hazard Analyses. Indian J Microbiol 51: 100-106.

32 Yang S, Angul, FJ, Altekruse SF (2000) Evaluation of safe foodhandling instructions on raw meat and poultry products. J Food Prot 63: 321-325.

33 Perez-Escamilla R, Vianna RPT (2012) Food insecurity and the behavioral and intellectual development of children: a review of the evidence. J Appl Res on Children: Informing policy for children at risk.

34 Silva CCS, Vianna RPT, Moraes RM, Santos SR, Santos GM et al. (2015). Artificial neural network and the decision support in nutritional food safety model. J Nurs UFPE on line 9: 7078-7085.

35 Barro N, Bello A, Aly S, Ouattara C, Ilboudo A, et al. (2006) Hygienic status and assessment of dish washing waters, utensils, hands, and pieces of money from street food processing sites in Ouagadougou, Burkina Faso. Afr J Biotechnol 5: 1107-1112.

36 Mensah P, Yeboah-Manu, Owusu-Darku K, Ablordey A (2002) Street Food in Accra, Ghana: How safe are they? Bulletin of the World Health Organization 80: 546-556.

37 Feglo P, Sakyi K (2012) Bacterial contamination of street vending food in Kumasi, Ghana. J Med Biomed Sci 1: 1-8.

38 Chesca AC, Teixeira AA, Costa CDC, Oliveira M, Araujo MDC, et al. (2000) Avaliação da temperatura das estufas de salgados de bares e lanchonetes do município de Uberaba, MG. Higiene Alimentar 11: 87-89. 
39 Food and Agriculture Organization (2001) Street foods alimentation de rue. Alimentos que se venden en la vía pública.

40 Calloni M (2013) Street food on the move: A socio-philosophical approach. J Sci Food Agric 93: 3406-3413.

41 Aluko OO, Ojeremi TT, Olakele DA, Ajidagba EB (2014) Evaluation of food safety and sanitary practices among food vendors at car parks in lle Ife, south-western Nigeria. Food Control 40: 165-171.

42 Ekanem EO (1998) The street food trade in Africa: safety and socioenvironmental issues. Food Control 9: 211-215.

43 Narain A, Janani, Narayanaswamy K (2015) Microbiological quality of selected street vended foods in Coimbatore, India. Afr J Microbio Res 9: 757-762.

44 Buscemi S, Mattina A, Rosafio G, Massenti FM, Galvano F, et al. (2014) Habitual street food intake and subclinical carotid atherosclerosis. Eat Weight Disord 19: 363-370.

45 Odoms-Young AM, Zenk S, Mason M (2009) Measuring food availability and access in African-American communities: implications for intervention and policy. Am J Prev Med 36: 145-150.

46 Valdez Z, Dean WR, Sharkey JR (2012) Mobile and home-based vendor's contributions to the retail food environment in rural South Texas Mexican-origin settlements. Appetite 59: 212-217.

47 Sharkey JR, Dean WR, Johnson CM (2012) Use of vendedores (mobile food vendors), pulgas (flea markets), and vecinos o amigos (neighbors or friends) as alternative sources of food for purchase among Mexican-origin households in Texas border Colonias. J Acad Nutr Diet 112: 705-710.

48 Tester JM, Yen IH, Laraia B (2010) Mobile food vending and the afterschool food environment. Am J Prev Med 38:70-73.

49 Steyn NP, Labadarios D, Nel JH (2011) Factors which influence the consumption of street foods and fast foods in South Africa-a national survey. Nutr J 10: 104.

50 Carrol R (2008) Haiti: mud cakes become staple diet as cost of food soars beyond a family's reach. The Guardian Accessed on: November 03, 2015.

51 Katz JM (2008) Poor Haitians resort to eating dirt. P M Est 7: 43.

52 Magdoff F (2008) The world food crisis: Sources and solutions.

53 United States Institute of Peace (2009) Haiti after the Donor's conference: a way forward Special report 232.

54 Riet HV, Hartog AP, Staveren WA (2002) Non-home prepared foods: contribution to energy and nutrient intake of consumers living in two low-income areas in Nairobi. Public Health Nutr 5: 515-522.

55 Wang S, Duan H, Zhang W, Li JW (2007) Analysis of bacterial foodborne disease outbreaks in China between 1994 and 2005. FEMS Immunol Med Microbiol 51:8-13.

56 Steyn NP, Mchiza Z, Hill J, Davids YD, Venter I, et al. (2013) Nutritional contribution of street foods to the diet of people in developing countries: a systematic review. Public Health Nutr 17: 1363-1374.

57 Oyunga-Ogubi MA, Waudo NJ, Afullo A, Oiye SO (2009) African Journal of Food, Agriculture, Nutrition and Development. Potential role of street foods as micronutrients source among low-income groups in Nairobi, Kenya. African J Food Agric Nut Dev 9: 1129-1145.

58 Lucan SC, Maroko AR, Bumol J, Varona M, Torrens L, et al. (2014) Mobile food vendors in urban neighborhoods - Implications for diet and dietrelated health by weather and season. Health \& Place 27: 171-175
59 Manguiat LS, Fang TJ (2013) Microbiological quality of chicken- and pork-based street-vended foods from Taichung, Taiwan, and Laguna, Philippines. Food Microbiol 36: 57-62.

60 Knight PG, Jackson JC, Bain B, Eldemire-Shearer D (2003) Household food safety awareness of selected urban consumers in Jamaica. Int J Food Sci Nutr 54: 309-320.

61 Center for Disease Control and Prevention (2007) (FoodNet 2007). Surveillance Report. Atlanta: US Department of Health and Human Services.

62 Chon JW, Lee WC, Lee MJ, Bang HA, Seo KH, et al. (2014) Food poisoning patterns in Korea J Prev Vet Med 38:79-83.

63 Stangarlin L, Hecktheuer LH, Serafim AL, Medeiros LB (2013) Hygienicsanitary conditions of hospital nutrition and dietary services. Food Sci Technol 33: 521-525.

64 Food and Agriculture Organization (1998) Food Quality and Safety Systems. A training manual on food hygiene and the Hazard Analysis and Critical Control Point (HACCP) system: 232.

65 World Health Organization (2008) Foodborne disease outbreaks: Guidelines for investigation and control.

66 El-Shenawy M, El-Shenawy, M Mañes J, Soriano JM (2011) Listeria spp. in street vended ready-to-eat foods. Int Perspect Infect Dis 28: 24-29.

67 Michino H, Otsuk K (2000) Risk factors in causing outbreaks of foodborne illness originating in school-lunch facilities in Japan. J Vet Med Sci 62: 557-560.

68 Code, KFDA Food (2008) Korea Food \& Drug Administration. Seoul, Korea74-114.

69 Center for Disease Control and Prevention - CDC. (2006). Surveillance for Foodborne-disease outbreaks - United States, 1998-2002. Morbidity and Mortality Weekly Report (MMWR).

70 Cho Jl, Cheung CY, Lee SM, Ko SI, Kim KH, et al. (2011) Assessment of microbial contamination levels of street-vended foods in Korea. $J$ Food Saf 31: 41-47.

71 Much P, Pitchler J, Alierberger F (2007) Foodborne infectious outbreaks, Austria 2005. Wien Klin Wochenschr 119: 150-157.

72 Greig JD, Ravel A (2009) Analysis of foodborne outbreak data reported internationally for source attribution. Int J Food Microbiol 130: 77-87.

73 Hughes C, Gillespie IA, O'brien SJ (2007) Foodborne transmission of infectious intestinal disease in England and Wales, 1992-2003. Food Control 18: 766-772.

74 Vaillant V, Valk H, Baron E, Ancelle T, Colin P, et al. (2005) Foodborne Infections in France. Foodborne Pathol Diseases 2: 221-232.

75 Mamun MA, Rahman S MM, Turin TC (2013) Microbiological quality of selected street food items vended by school-based street food vendors in Dhaka, Bangladesh. Int J Food Microbiol 166: 413-418.

76 Burt BM, Volel C, Finkel M (2003) Safety of vendor-prepared foods: evaluation of 10 processing mobile food vendors in Manhattan. Public Health Rep 118: 470-476.

77 Campos J, Gil J, Mourão J, Antunes LPP (2015) Ready-to-eat streetvended food as a potential vehicle of bacterial pathogens and antimicrobial resistance: An exploratory study in Porto region, Portugal. Int J Food Microbiol 206: 1-6.

78 Bhattacharjya H, Reang T (2014) Safety of street foods in Agartala, North East India. Public Health 128: 746-748. 
79 Okojie PW, Isah EC (2014) Sanitary Conditions of Food Vending Sites and Food Handling Practices of Street Food Vendors in Benin City, Nigeria: Implication for Food Hygiene and Safety. J Environ Public Health 16: 6.

80 Cardinale E, Abat C, Bénédicte C, Vincent P, Michel R, et al. (2015) Salmonella and Campylobacter Contamination of Ready-to-Eat Street-Vended Pork Meat Dishes in Antananarivo, Madagascar: A Risk for the Consumers? Foodborne Pathog Dis 12: 197-202.

81 Danish Integrated Antimicrobial Resistance Monitoring and Research Programme - DANMAP (2013) DANMAP 2012 - use of antimicrobial agents and occurrence of antimicrobial resistance in bacteria from food animals, food and humans in Denmark.

82 European Food Safety Authority and European Centre for Disease Prevention and Control - EFSA and ECDC -. (2015). The European Union Summary Report on trends and sources of zoonoses, zoonotic agents and food-borne outbreaks in 2013. EFSA J 13: 3991

83 Campos J, Mourão J, Pestana N, Peixe L, Novais C (2013) Microbiological quality of ready-to-eat salads: an underestimated vehicle of bacteria and clinically relevant antibiotic resistance genes. Int J Food Microbiol 166: 464-470.

84 World Health Organization - WHO (2003) Food Safety: issuesPublic Health Significance of Foodborne Illnesses. World Health Organization, Food Safety Program, Regional Office for the Western Pacific, WHO.

85 Frazzoli C, Petrini C, Mantovani A (2009) Sustainable development and next generation's health: a long-term perspective about the consequences of today's activities for food safety. Ann 45: 65-75.

86 Ababio PF, Lovatt P (2015) A review on food safety and food hygiene studies in Ghana. Food Control 47: 92-97.

87 Cano JMM, Díaz A, Alamilla CJ, Caballero D, Pool J, et al. (2014) Effect of eating Oreochromis aureus on biochemical markers in young people. J Nutr Food Sci 4: 283.

88 Popkin BM (2002) What is unique about the experience in lowerand middle-income less-industrialized countries compared with the very-high-income industrialized countries? The shift in stages of the nutrition transition in the developing world differs from past experiences. Public Health Nutr 5: 205-214.

89 Popkin BM (2004) The nutrition transition: an overview of world patterns of change. Nutr Rev 62: 140-143.

90 Haslam DW, James WPT (2005) Obesity. Lancet 366: 1197-1209.

91 Lobstein T, Baur L, Uauy R (2006) Obesity in children and young people: a crisis in public health. Obes Rev 5: 4-104.

92 Mwangi AM, den Hartog AP, Mwadime RKN (2002) Do street food vendors sell a sufficient variety of foods for a healthful diet? The case of Nairobi. Food Nutr Bull 23: 48-56.

93 Draper A (1996) Street Foods in Developing Countries: The Potential for Micronutrient Fortification. John Snow, Inc/OMNI Project.

94 Sanni SA, Oguntona CRB, Sanni LO (1999) Chemical and Nutritional Composition of Some Common Foods in Abeokuta, Nigeria. Braz Arch Biol Technol 42: 331-338.

95 Buscemi S, Barile A, Maniaci V, Batsis JA, Mattina A (2011) Characterization of Street Food consumption in Palermo: possible effects on health. Nutr J 10: 119.

96 Buscemi S, Maniaci V, Barile AM, Rosafio G, Mattina A, et al. (2012) Endothelial function and other biomarkers of cardiovascular risk in frequent consumers of street food. Clin Nutr 31: 934-939.

97 Malik VS, Schulze MB, Hu FB (2006) Intake of sugar-sweetened beverages and weight gain: a systematic review. Am J Clin Nutr 84: 274-288.

98 Pereira MA, Kartashov Al, Ebbeling CB, Van Horn L, Jacobs DR Jr (2005) Fast-Food Habits, Weight Gain, and Insulin Resistance (the CARDIA Study): 15-year prospective analysis. Lancet 365: 36-42.

99 Rosenheck R (2008) Fast food consumption and increased caloric intake: a systematic review of a trajectory towards weight gain and obesity risk. Obesity Rev 9: 535-547.

100 Koodagi K, Mahesha HM, Sanath Kumar VB (2013) Macronutrient Status of Street Foods. J Nutr Food Sci 3: 198 